\title{
Maximization of genetic gain in rubber tree (Hevea) breeding with effective size restriction
}

\author{
Reginaldo Brito da Costa ${ }^{I}$, Marcos Deon Vilela de Resende ${ }^{2}$, Antônio José de Araújo \\ Paulo de Souza Gonçalves ${ }^{4}$ and Marcelo de Almeida Silva ${ }^{5}$
}

\begin{abstract}
The heritability coefficients and the genetic gains associated with individual, combined and among and within progeny selection, and with multi-effect index selection in long-term rubber tree [Hevea brasiliensis (Willd. ex Adr. de Juss.) Muell.-Arg.] breeding were determined using effective population size $(\mathrm{Ne})$ restriction. Twenty-two half sib progenies were planted at the Jaú Experimental Station, São Paulo State, Brazil, in a complete randomized block design, with five replications and 10 plants per plot. The following traits were assessed when the plants were three years old: number of laticiferous vessel rings (NR), dry rubber production (RP), bark thickness (BT) and stem girth (SG). Significant variability was found among progeny with good chances of obtaining genetic gain for RP, BT and SG. Effective population size restriction caused a greater reduction in genetic gain for RP with combined selection and with the multi-effect index than for individual or among and within progeny selection. The simultaneous use of accuracy values and genetic gain from the lower limits of the confidence intervals for gain indicated that individual selection is to be preferred in Hevea breeding programs.
\end{abstract}

\section{INTRODUCTION}

Rubber tree improvement [Hevea brasiliensis (Willd. ex Adr. de Juss.) Muell.-Arg.] has been achieved by incorporating new sources of genetic variability to yield high rubber production and disease resistance, especially against South American leaf blight. Suitable leaf diseasefree areas have been chosen for cultivation, and São Paulo State has become the largest dry rubber producer in Brazil (Boock et al., 1995). In contrast, the rational use of genetic variability in natural rubber tree populations has been minimal (Paiva and Kageyama, 1993).

Progeny tests, one of plant breeder's most important tools, have been used to estimate genetic parameters and to select among the progenies. These tests have also been used on rubber to assess the magnitude and nature of the available genetic variance to quantify the gains with selection and to predict the best selection method (Gonçalves et al., 1985, 1996, 1999; Moreti et al., 1994; Boock et al., 1995). The adequate use of progeny tests requires knowledge of the heritability and accuracy associated with the selection units and genetic progress in the cuttings or clones.

The simultaneous consideration of genetic gain and accuracy becomes more meaningful when the confidence intervals for the genetic gains are known. In general, the more accurate methods have narrower limits for the interpretation of confidence intervals. Thus, the lower rather than the upper limits of the intervals should be considered when choosing the best selection method, since methods with higher lower limits are better because they allow safer selection.

Appropriate selection procedures should be determined by comparing the genetic progress and increase in inbreeding provided by the different selection methods used. Resende and Bertolucci (1995) emphasized that selection based only on genetic values may lead to inbreeding depression in an advanced generation. The main causes are self fertilization and the presence of related individuals in the reproducing populations, the loss of favorable alleles and the difficulty of attaining selection limits in breeding populations because of a reduction in the effective population size $(\mathrm{Ne})$.

Genetic variability in a breeding population needs to be preserved to sustain a long-term breeding program. This may be done by maximizing the genetic gain, while restricting the Ne.

Long-term genetic gain depends on the potential genetic variability, i.e., variability which is maintained throughout the selective cycles and is released by recombination at the end of each such cycle. Thus, the question of establishing breeding populations should be analyzed by considering selective limits theory (Robertson, 1960). The safest approach (without risk of favorable allele loss) to reaching the selection limit of the populations involves the maintenance of a compatible Ne.

\footnotetext{
${ }^{I}$ Curso de Biologia/Zootecnia, Programa Desenvolvimento Local,

Universidade Católica Dom Bosco, Av. Tamandaré, 6000, Caixa Postal 100, 79117-100 Campo Grande, MS, Brasil. ${ }^{2}$ Embrapa Florestas, Caixa Postal 319, 83411-000 Colombo, PR, Brasil. 
Since there is little information on $\mathrm{Ne}$ for rubber tree, there is a need to examine the genetic gains obtained by different selection methods. Individual selection (among and within progenies), as well as combined and multi-effect index selection should be compared, in order to maintain the genetic variability while increasing inbreeding within the population. Selection based on the multi-effect index maximizes the genetic progress of a trait, independent of the experimental structure, primarily because this index is a product of the phenotypic values of the individual, plot mean, family mean, block mean and general mean of the experiment, expressed as weighted coefficients of the index (Resende and Higa, 1994).

Resende and Bertolucci (1995) showed that selection by the multi-effect index was always superior to combined selection since it produced greater genetic gain, accuracy, effective population size and intensity of selection. We estimated the magnitudes of the heritability coefficients in the rubber tree and compared the genetic gains provided by individual, combined and multi-effect index selection, using the restriction of $\mathrm{Ne}$ and the lower confidence limit for gain as parameters.

\section{MATERIAL AND METHODS}

The genetic material consisted of 22 half-sib progenies from open pollinated seeds, obtained from 22 parental clones phenotypically selected in an $\mathrm{H}$. brasiliensis population of Asian origin established at the Campinas Experimental Station (IAC) in 1952. The experiment was set up at Jaú Experimental Station (latitude $22^{\circ} 17^{\prime}$ 'S, longitude $48^{\circ} 34^{\prime} \mathrm{W}$ and $580 \mathrm{~m}$ altitude). The soil is clay textured dark red latosoil, deep and flat with a well-drained topography. An Aw (Köppen) climate predominates in this region, with a defined dry season, annual mean temperature of $21.6^{\circ} \mathrm{C}$, average humidity of $70 \%$ with extremes of $77 \%$ in February and 59\% in August. The mean annual rainfall is $1,344 \mathrm{~mm}$.

The seeds were collected at the IAC, placed in polyethylene bags and germinated at the experimental station and taken to their definitive locations when they showed two leaf umbrellas. The seedlings were set out in a randomized complete block design with 22 treatments, five replications and 10 plants per plot spaced $1.5 \mathrm{~m}$ apart in single rows.

The following traits were assessed in the progenies when they were three years old:

a) Dry rubber production (RP): obtained by the $\mathrm{Ha}-$ maker-Morris-Mann (HMM) test modified for three-yearold seedlings (Tan and Subramanian, 1986) using the mean dry rubber production from three series of 10 tappings per plant. The tapping panel was opened $20 \mathrm{~cm}$ from the soil, using the $1 / 2 \mathrm{~S} \mathrm{~d} / 3$ system, in a total of 35 cuts, discarding the first five samples which corresponded to the "breaking in of the panel" stage. The term $1 / 2 \mathrm{~S}$ corresponds to the half spiral and the term $\mathrm{d} / 3$ indicates the interval between tappings, i.e., tapping every three days.

b) Stem girth (SG): determined at $50 \mathrm{~cm}$ from the soil, with the help of a graduated tape measure, and expressed in centimeters.

c) Bark: Two bark samples were removed from the stem as plugs at $15 \mathrm{~cm}$ from the soil and the following parameters then determined: 1) bark thickness (BT): measured in $m m$ with a pachymeter and 2) total number of rubber vessel rings (NR): assessed by examining a longitudinal radial section of the bark sample.

The statistical model analysis considered all variables (except the mean) as random effects:

$$
\mathrm{Y}_{i j l}=\mu+\mathrm{p}_{i}+\mathrm{b}_{j}+\mathrm{e}_{i j}+\mathrm{d}_{i j l}
$$

where $Y_{i j l}=$ observed value of the $l$ th plant, in the $j t h$ replication, within the ith progeny, $\mu=$ general mean, $\mathrm{p}_{i}=$ effect of the $i t h$ progeny $(i=1,2, \ldots \ldots \ldots, \mathrm{p}), \mathrm{b}_{j}=$ effect of the $j$ th replication $(j=1,2, \ldots \ldots \ldots, \mathrm{b}), \mathrm{e}_{i j}=$ experimental error associated with the ith progeny, of the $j$ th plot, and $\mathrm{d}_{i j l}=$ effect of the $l$ th plant, within the $i j t h$ plot.

Estimates of the genetic and phenotypic parameters were obtained using the SELEGEN genetic statistical software developed by Resende et al. (1994). The heritability coefficient at the individual within plot level $\left(\mathrm{h}_{d}^{2}\right)$, progeny mean $\left(h_{f}^{2}\right)$, plot mean $\left(h_{p}^{2}\right)$, individual within blocks $\left(\mathrm{h}_{i b}^{2}\right)$ and individual plants $\left(\mathrm{h}_{i e}^{2}\right)$ associated with the different effects of the linear model were estimated by the following expressions (Resende and Higa, 1994).

$$
\begin{aligned}
& \mathrm{h}_{d}^{2}=\frac{3 / 4 \sigma_{A}^{2}}{\sigma_{d}^{2}} \\
& \mathrm{~h}_{f}^{2}=\frac{[(3+n b) /(4 n b)] \sigma_{A}^{2}}{\sigma_{p}^{2}+\frac{\sigma_{e}^{2}}{b}+\frac{\sigma_{d}^{2}}{n b}} \\
& \mathrm{~h}_{p}^{2}=\frac{[3 /(4 n)] \sigma_{A}^{2}}{\sigma_{e}^{2}+\frac{\sigma_{d}^{2}}{n}} \\
& \mathrm{~h}_{i b}^{2}=\frac{\sigma_{A}^{2}}{\sigma_{p}^{2}+\sigma_{e}^{2}+\sigma_{d}^{2}} \\
& \mathrm{~h}_{i e}^{2}=\frac{\sigma_{A}^{2}}{\sigma_{p}^{2}+\sigma_{e}^{2}+\sigma_{d}^{2}+\sigma_{b}^{2}}
\end{aligned}
$$

where: $\sigma_{A}^{2}=4 \sigma_{p}^{2}, \sigma_{A}^{2}=$ additive genetic variance, $\sigma_{e}^{2}=$ among plots environmental variance, $\sigma_{d}^{2}=$ among plants within plots phenotypic variance, $\sigma_{p}^{2}=$ among progenies genetic variance, $n=$ number of plants/plot and $b=$ number of blocks.

The coefficients of genetic $\left(\mathrm{CV}_{\mathrm{g}} \%\right)$ and experimental $\left(\mathrm{CV}_{\mathrm{e}} \%\right)$ variation were estimated using the formulas presented by Vencovsky (1987): 


$$
\begin{aligned}
& \mathrm{CV}_{\mathrm{g}}(\%)=\frac{\sqrt{\sigma_{p}^{2}}}{\bar{X}} \cdot 100 \\
& \mathrm{CV}_{\mathrm{e}}(\%)=\frac{\sqrt{\sigma_{e}^{2}+\sigma_{d}^{2}}}{\bar{X}} \cdot 100
\end{aligned}
$$

Estimates of the genetic values and the genetic progress were obtained by individual $\left(\mathrm{I}_{\mathrm{i}}\right)$, among $\left(\mathrm{I}_{\mathrm{a}}\right)$, within $\left(I_{w}\right)$, on combined $\left(I_{c}\right)$ selection and by the multi-effect in$\operatorname{dex}\left(\mathrm{I}_{\mathrm{me}}\right)$ in univariate situations, using the expressions described by Resende and Higa (1994):

$$
\begin{aligned}
\mathrm{I}_{\mathrm{i}}= & \mathrm{h}_{i e}^{2}\left(X_{i j k}-\bar{X}_{. . .}\right) \\
\mathrm{I}_{\mathrm{a}}= & h_{f}^{2}\left(\bar{X}_{i . .}-\bar{X}_{. .}\right) \\
\mathrm{I}_{\mathrm{w}}= & h_{d}^{2}\left(Y_{i j k}-\bar{Y}_{i j}\right) \\
\mathrm{I}_{\mathrm{c}}= & h_{d}^{2} \cdot X_{i j k}-h_{d}^{2} \cdot \bar{X}_{i j .}+h_{f}^{2} \cdot \bar{X}_{i . .}-h_{f}^{2} \cdot \bar{X}_{\ldots .} \\
\mathrm{I}_{\mathrm{me}}= & h_{d}^{2}\left(Y_{i j k}\right)+\left(h_{p}^{2}-h_{d}^{2}\right) \bar{X}_{i j .}-h_{p}^{2} \bar{X}_{j .}+ \\
& +\left(h_{f}^{2}-h_{p}^{2}\right) \bar{X}_{i . .}+\left(h_{p}^{2}-h_{f}^{2}\right) \bar{X}_{\ldots . .}
\end{aligned}
$$

where $\mathrm{h}^{2}{ }_{i e}$ is the heritability coefficient in the restricted sense at the individual level in the experiment, $X_{i j k}$ is the value of the $k t h$ individual in the $i j t h$ plot, $\bar{X}$ is the general experimental mean, $\bar{X}_{i . .}$ is the family mean, $\bar{X}_{i j .}$ is the plot mean, $X_{i j k}$ is the deviation of the individual value (plot) and $\bar{X}_{j .}$ is the block mean.

The progress with selection among and within progenies was equivalent to the sum of the gains obtained in the selection among and within progenies, whereas the progress with combined selection was equivalent to the mean of the genetic values (index) of the selected individuals.

Selection by the multi-effect index was based on the product of the individual phenotypic value, plot mean, family mean, block mean and the general mean of the experiment using the index-weighting coefficients.

The index-weighting coefficients were determined to maximize the correlation between the index and the genetic value. This maximization was obtained by regressing the genetic value on the phenotypic values, which leads to a matrix system (Henderson, 1963).

The following accuracy estimators derived by Resende et al. (1995) for the different selection methods were used:

a) Individual: $\left(\frac{\sigma_{A}^{2}}{\sigma_{F i e}^{2}}\right)^{1 / 2}$

b) Among and within progeny selection (selection at two stages):

b.1. Among progeny selection

$$
\left(\frac{p-1}{p}\right)^{1 / 2} \frac{1+(n b-1) r}{n b} \sigma_{A} / \sigma_{\bar{F}}
$$

b.2. Within progeny selection

$$
\left(\frac{n-1}{n}\right)^{1 / 2}(1-r) \sigma_{A} / \sigma_{d}
$$

c) Combined selection

$$
\left[\frac{n-1}{n}(1-r)^{2} \frac{\sigma_{A}^{2}}{\sigma_{d}^{2}}+\frac{p-1}{p}\left(\frac{1+(n b-1) \mathrm{r}}{n b}\right)^{2} \frac{\sigma_{A}^{2}}{\sigma_{\bar{F}}^{2}}\right]^{1 / 2}
$$

d) Multi-effect index selection

$$
\begin{aligned}
& {\left[\frac{n-1}{n}(1-r)^{2} \frac{\sigma_{A}^{2}}{\sigma_{d}^{2}}+\frac{p-1}{p}\left(\frac{1+(n b-1) r}{n b}\right)^{2} \frac{\sigma_{A}^{2}}{\sigma_{\bar{F}}^{2}}+\right.} \\
& \left.+\left(\frac{b-1}{b}\right)\left(\frac{p-1}{p}\right)\left(\frac{1-r}{n}\right)^{2} \frac{\sigma_{A}^{2}}{\sigma^{2}}\right]^{1 / 2}
\end{aligned}
$$

where $\sigma_{\bar{F}}^{2}=$ genotypic variance at the family mean level, $\sigma_{F_{i}}^{2}=$ phenotypic variance at the individual level, $\sigma^{2}=$ residual variance at the plot level, $r=$ genetic correlation coefficient among individuals of a single progeny ( $1 / 4$ for half sibs) and $n, b, p=$ number of plants per plot, block and progeny, respectively.

The accuracy parameter is a very useful measurement of the precision of the genetic values predicted and corresponds to the correlation between the true and the predicted genetic values. The confidence intervals for the genetic gains were obtained by estimating the variance of the error associated with the predicted additive genetic values (Resende et al., 1995):

$$
C I=G s \pm t\left[1 / N\left[\sigma_{A}^{2}\left(1-r_{l, A}^{2}\right)\right]\right]^{1 / 2}
$$

where $t=$ tabulated value associated with Student's $t$ distribution, $N=$ number of individuals selected and $r_{l, A}^{2}=$ selective accuracy associated with different selection methods.

The effective population size, assuming a cross pollinating population, was calculated as described by Vencovsky (1978) for selection in both sexes using non-related progeny structures.

$$
N e=4 P_{s} \cdot n /\left(\frac{\sigma_{n}^{2}}{\bar{n}}+\bar{n}+3\right)
$$

where $P_{s}=$ number of selected progenies, $\bar{n}=$ mean number of selected individuals and $\sigma_{n}^{2}=$ variance of the number of selected individuals.

The following relationships were derived from the expression described by Resende and Bertolucci (1995): 
1. Selection of one individual in each progeny: $N_{e}=P_{s}$

2. Equal number of individuals selected per progeny: $N_{e}=4 P_{s} \cdot n /(\bar{n}+3)$

The following biometrical concepts were applied to the production population:

a) Probability of identity by descent or inbreeding coefficient (reflects self pollination and crossing among related individuals)

$$
F=1 /(2 N e)
$$

b) Corrected genetic gain $\left(G_{s c}\right)$ for inbreeding depression

$$
G_{s c}=(1-F) G_{s}=[1-1 /(2 N e)] G_{s},
$$

where $G_{s}$ is the uncorrected genetic gain.

Inbreeding depression $(H)$ was considered to change

at the same rate as $F$ and therefore,

$$
G_{s c}=G_{s}-F H=G_{s}-[1 /(2 N e)] H
$$

c) Inbreeding coefficient due to self pollination:

$$
F=(1 / N) F_{s}=(1 / N) 1 / 2=1(2 N),
$$

where $F_{s}=$ inbreeding coefficient of individuals from self pollination.

\section{RESULTS AND DISCUSSION}

There were significant among family differences for all the traits (F-test, Table I). This variability was an essential condition for establishing a breeding program to increase rubber production.

The experimental coefficients of variation $\left(\mathrm{CV}_{\mathrm{e}} \%\right)$ obtained for NR, BT and SG (Table I) may be considered low and indicate good experimental precision and good assessment criteria. The $\mathrm{CV}_{\mathrm{e}}$ for RP indicated that this parameter was subject to greater experimental errors. However, the RP value was considered average when compared to the estimates of Paiva et al. (1982) and Alves et al. (1987). These authors obtained $\mathrm{CV}_{\mathrm{e}}$ for RP of 38.3 and $50.4 \%$ and levels of RP similar to that reported by Moreti et al. (1994).

The coefficients of genetic variation, expressed as percentages of the general mean, were higher for RP, BT and $\mathrm{SG}$, indicating greater genetic variation for these traits. These results agree with those of Gonçalves et al. (1983), Moreti et al. (1994) and Boock et al. (1995) and confirmed the variability in the species detected by the progenies F-test. The results also indicate that the breeding program for increased productivity can be continued.

At the individual level, the heritability estimates for NR, RP, BT and SG (Table II) can be considered low. However, they agree with those reported elsewhere for this species (Tan et al. 1975; Tan and Subramanian, 1975; Alika and Onokpise, 1982; Paiva et al., 1982; Alika, 1985; Boock et al., 1995).

The effective population size required to obtain a genetic gain in the long term has been the subject of several theoretical studies (Robertson, 1960; Rawlings, 1970; Vencovsky and Godoy, 1976; Kang, 1979; Pereira and
Vencovsky, 1988). In the present study, the approach of Pereira and Vencovsky (1988), in which the heritability and inbreeding coefficient of the population are taken into account, was used to choose an $\mathrm{Ne}=50$. This value was suitable for the heritability of the rubber production trait $\left(\mathrm{h}_{i e}^{2}=0.10\right.$ in this study) and for the inbreeding coefficient of the population studied.

\begin{tabular}{|c|c|c|c|c|}
\hline $\begin{array}{l}\text { Source of } \\
\text { variation }\end{array}$ & NR & $\mathrm{RP}(\mathrm{g})$ & $\mathrm{BT}(\mathrm{mm})$ & $\mathrm{SG}(\mathrm{cm})$ \\
\hline Replications & 0.1018 & 0.0387 & 0.7362 & 18.8466 \\
\hline Progenies & $0.0511 * *$ & $0.0972 *$ & $1.1881^{* *}$ & $35.9600 * *$ \\
\hline Residual & 0.0164 & 0.0474 & 0.2161 & 6.4796 \\
\hline Within plot & 0.2537 & 0.3522 & 2.3824 & 65.0088 \\
\hline Mean & 1.6636 & 0.6381 & 3.1640 & 14.3484 \\
\hline $\begin{array}{l}\text { Experimental } \\
\text { coeff. of variation }\end{array}$ & 7.7090 & 34.1135 & 14.6917 & 17.7407 \\
\hline $\begin{array}{l}\text { Genetic coeff. } \\
\text { of variation }\end{array}$ & 5.0029 & 15.6401 & 13.9350 & 16.9230 \\
\hline
\end{tabular}

Table I - Mean square values of ANOVA for total number of vessel rings (NR), rubber production (RP), bark thickness (BT) and stem girth (SG) for three-year-old progenies of Hevea brasiliensis.

${ }^{1}$ The degrees of freedom for replications, progenies and residual were 4,21 and 84 , respectively. ${ }^{*} \mathrm{P}<0.05 ; * * \mathrm{P}<0.01$

Table II - Heritability coefficients for total number of vessel rings (NR), rubber production (RP), bark thickness (BT) and stem girth (SG) for different comparisons in three-year-old progenies of Hevea brasiliensis.

\begin{tabular}{|lcccc|}
\hline Heritabilities & NR & RP & BT & SG \\
\hline Individual within plot level $\left(h_{d}^{2}\right)$ & 0.082 & 0.085 & 0.245 & 0.272 \\
Progeny mean $\left(h_{f}^{2}\right)$ & 0.719 & 0.543 & 0.867 & 0.869 \\
Plot mean $\left(h_{p}^{2}\right)$ & 0.126 & 0.063 & 0.270 & 0.273 \\
Individual within blocks $\left(\mathrm{h}_{i b}\right)$ & 0.110 & 0.106 & 0.304 & 0.333 \\
Individual plants $\left(h_{i e}^{2}\right)$ & 0.108 & 0.106 & 0.301 & 0.330 \\
\hline
\end{tabular}

Table III - Estimates of genetic gain $(\mathrm{G})$ in rubber production

\begin{tabular}{|c|c|c|c|c|c|}
\hline \multirow[t]{2}{*}{ Selection methods } & \multicolumn{2}{|c|}{$\mathrm{Ne}=50$} & \multicolumn{2}{|c|}{$\mathrm{N}=50$} & \multirow[t]{2}{*}{$\mathrm{r}_{(\mathrm{I}, \mathrm{A})} *$} \\
\hline & $\mathrm{G}(\%)$ & $\mathrm{Ne}$ & $\mathrm{G}(\%)$ & $\mathrm{Ne}$ & \\
\hline Individual $\left(\mathrm{I}_{i}\right)$ & 17.6 & 160 & 27.1 & 26 & 0.33 \\
\hline Among progenies $\left(\mathrm{I}_{a}\right)$ & 7.0 & 700 & - & - & 0.37 \\
\hline Within progenies $\left(\mathrm{I}_{w}\right)$ & 14.6 & $88 * *$ & - & - & 0.24 \\
\hline \multicolumn{6}{|l|}{ Among and } \\
\hline within progenies $* * *$ & 16.1 & 100 & 23.7 & 25 & $(0.37+0.24)$ \\
\hline Combined $\left(\mathrm{I}_{c}\right)$ & 11.9 & 502 & 31.2 & 13 & 0.44 \\
\hline Multi-effect index $\left(\mathrm{I}_{m e}\right)$ & 12.0 & 504 & 32.3 & 13 & 0.45 \\
\hline
\end{tabular}
using different selection methods based on an effective population size $(\mathrm{Ne})$ of 50 , and 50 selected individuals $(\mathrm{N})$ in three-year-old progenies of Hevea brasiliensis.

$* r_{(\mathrm{I}, \mathrm{A})}=$ Selective accuracy associated with different selection methods; **four individuals in each of 22 progenies; ***twenty progenies and five individuals per progeny was the best combination (maximum gain) for the number of families and individuals per family. 
Table IV - Estimates of genetic gain (G) and total number of individuals selected (N) for different selection methods, based on a restricted number (n) of selected individuals per progeny. The effective population size for rubber production was restricted to 50 .

\begin{tabular}{|c|c|c|c|c|c|c|c|c|c|c|}
\hline \multirow[t]{2}{*}{ Selection method } & \multicolumn{2}{|c|}{$\mathrm{n}=3$} & \multicolumn{2}{|c|}{$\mathrm{n}=4$} & \multicolumn{2}{|c|}{$\mathrm{n}=5$} & \multicolumn{2}{|c|}{$n=6$} & \multicolumn{2}{|c|}{$\mathrm{n}=7$} \\
\hline & $\mathrm{G}(\%)$ & $\mathrm{N}$ & $\mathrm{G}(\%)$ & $\mathrm{N}$ & $\mathrm{G}(\%)$ & $\mathrm{N}$ & $\mathrm{G}(\%)$ & $\mathrm{N}$ & $\mathrm{G}(\%)$ & $\mathrm{N}$ \\
\hline Individual $\left(\mathrm{I}_{i}\right)$ & 21.8 & 66 & 20.1 & 88 & 20.2 & 98 & 19.8 & 109 & 19.6 & 117 \\
\hline Combined $\left(\mathrm{I}_{c}\right)$ & 15.9 & 66 & 14.6 & 88 & 16.6 & 99 & 17.1 & 111 & 17.4 & 122 \\
\hline Multi-effect index $\left(\mathrm{I}_{m e}\right)$ & 16.8 & 66 & 15.6 & 88 & 17.5 & 99 & 18.1 & 111 & 18.4 & 122 \\
\hline
\end{tabular}

At the same intensity of selection $(\mathrm{N}=50)$ the best methods for genetic gain were selection by the multi-effect index (6) and combined selection (5). However, these methods yielded lower $\mathrm{Ne}$ values. The restricted $\mathrm{Ne}$ of 50 reduced the selection intensity and the best methods were individual selection (1) and among and within progeny selection (4). Restricting the number (n) of individuals selected by progeny (method 4) was advantageous compared to the reduced intensity of selection (methods 2, 5 and 6). Restricting the number of individuals selected per progeny was another alternative for increasing the value of $\mathrm{Ne}$ which also led to a reduction in the variance of $n$.

Among several alternatives for restricting NE to 50, the best one was that which restricted $\mathrm{n}=3$ individual selection (Tables III and IV). For combined selection, the best alternative was $n=7$, whereas for the multi-effect index the best alternative was $n=7$ (Table IV).

Based on results for Ne restriction, there was no superiority in terms of genetic gain for combined selection and/or the multi-effect index over individual selection. $\mathrm{Ne}$ restriction caused a greater reduction in genetic gain with combined selection and the multi-effect index than with individual selection; this reduction was less expressive with the multi-effect index.

A breeder's decision should be based not only on genetic gain but also on the accuracy of selection and confidence intervals of the genetic gain. The reliability of the genetic value predicted depends mainly on accuracy (Van Vleck et al., 1987), and a reduced accuracy may produce considerable errors in the predicted values. Resende et al. (1995) emphasized that the choice of the best selection method should be based on the simultaneous use of

Table V - Genetic gains for accuracies and genetic gain ranges for rubber production for three different methods of selection in three-year-old rubber tree progenies, in Jaú.

\begin{tabular}{|llll|}
\hline $\begin{array}{l}\text { Selection } \\
\text { method }\end{array}$ & Accuracies & \multicolumn{2}{c|}{ Genetic gains $\%$} \\
\cline { 3 - 4 } & & Value & Range \\
\hline Individual $\left(\mathrm{I}_{i}\right)$ & 0.33 & 21.75 & $14.41-28.65$ \\
Combined $\left(\mathrm{I}_{c}\right)$ & 0.44 & 17.39 & $12.23-22.20$ \\
Multi-effects $\left(\mathrm{I}_{m e}\right)$ & 0.45 & 18.36 & $13.22-23.13$ \\
\hline
\end{tabular}

accuracy and genetic gain, using the confidence intervals of the genetic progress (Table V).

Based on the above results, the best selection method for Hevea was individual selection, since the restriction $\mathrm{n}=3$ resulted in the greatest genetic gain and lowest lower limit of the confidence interval for gain (Tables IV and V). This approach should provide the breeder with a greater chance of maintaining an effective population size compatible with that required to achieve the selective limit of the breeding population.

\section{ACKNOWLEDGMENTS}

The authors are grateful to Dr. Mario Campana, searcher from Jau Experimental Station for the field work, Mrs. Lígia Regina Lima Gouvêa and Mrs. Rosemeire Moreira Boschini for the laboratory work. R.B.C. is the recipient of a CAPES fellowship. Research supported by Fundação de Amparo à Pesquisa do Estado de São Paulo (FAPESP), and Coordenação de Aperfeiçoamento de Pessoal de Ensino Superior (CAPES). Publication supported by FAPESP.

\section{RESUMO}

O presente trabalho objetivou estimar os coeficientes de herdabilidade e comparar os ganhos genéticos obtidos através dos métodos: seleção individual, entre e dentro de progênies, combinada e índice multi-efeitos, considerando-se a restrição do tamanho efetivo populacional ( $\mathrm{Ne}$ ) com vistas ao melhoramento a longo prazo de uma população de seringueira [Hevea brasiliensis (Willd ex Adr. de Juss.) Muell.-Arg.]. Vinte e duas progênies de meio-irmãos foram plantadas na Estação Experimental de Jaú, SP, no delineamento de blocos ao acaso, com cinco repetições e dez plantas por parcela. Aos três anos de idade foram avaliados os caracteres: número de anéis de vasos laticíferos, produção de borracha seca, espessura de casca e circunferência do caule. Os resultados demonstraram haver variabilidade significativa entre progênies e grandes possibilidades de ganho genético para os caracteres produção de borracha, espessura de casca e circunferência do caule. A restrição do Ne promove maiores reduções do ganho genético na seleção combinada e no índice multi-efeitos que na seleção entre e dentro e individual, para o caráter produção de borracha. No presente estudo, a utilização simultânea dos valores de acurácia e ganho genético através do limite inferior do intervalo de confiança do ganho tornou preferível a utilização do método de seleção individual. 


\section{REFERENCES}

Alika, J.E. (1985). Heritability and genotype gain from selection in rubber (Hevea brasiliensis). Silvae Genet. 34: 1-4.

Alika, J.E. and Onokpise, O.U. (1982). Estimation of herdability parameter for yield, girth and bark thickness in rubber (Hevea brasiliensis) from a single pair mating (S.P.M.) design. J. Plant. Crops 10: 102-108.

Alves, M.R., Bandel, G. and Vencovsky, R. (1987). Avaliação de seleção em seringueira (Hevea spp). Bol. Fac. Ciênc. Agr. Pará, 16: 53-63.

Boock, M.V., Gonçalves, P. de S., Bortoletto, N. and Martins, A.L.M. (1995). Herdabilidade, variabilidade genética e ganhos genéticos para produção e caracteres morfológicos em progênies jovens de seringueira. Pesqui. Agropecu. Bras. 30: 673-681.

Gonçalves, P. de S., Rossetti, A.G., Valois, A.C.C. and Viegas, I. de J.M. (1983). Coeficiente de determinação genotípica e estimação de outros parâmetros em clones de seringueira. Pesqui. Agropecu. Bras. 18: 527-532.

Gonçalves, P. de S., Paiva, J.R., Vasconcelos, M.E. da C. and Valois, A.C.C. (1985). Progeny test of early Hevea hybrids for producing rapid-growing and high-yielding ortets. Rev. Bras. Genet. VIII: 319-327.

Gonçalves, P. de S., Martins, A.L.M., Bortoletto, N. and Tanzini, M.R. (1996). Estimates of genetic parameters and correlations of juvenile characters based on open pollinated progenies of Hevea. Braz. J. Genet. 19: 105-111.

Gonçalves, P. de S., Furtado, E.L., Bataglia, O.C., Ortolani, A.A., May, A. and Belletti, G.O. (1999). Genetics of anthracnose panel canker disease resistance and its relationship with yield and growth characters in half-sib progenies of rubber tree (Hevea brasiliensis). Genet. Mol. Biol. 22: 583-589.

Henderson, C.R. (1963). Selection index and expected genetic advance. In Statistical Genetics and Plant Breeding (Hanson, W.D. and Robinson, A.F., eds.). Publication 982 NAS-NRS, Washington D.C., pp.141-163.

Kang, H. (1979). Long-term tree breeding. In: Proceedings of 15th Southern Forest Tree Improvement Conference, Mississipi State, pp. 66-72.

Moreti, D., Gonçalves, P. de S., Gorgulho, E.P., Martins, A.L.M. and Bortoletto, N. (1994). Estimativas de parâmetros genéticos e ganhos esperados com a seleção de caracteres juvenis em progênies de seringueira. Pesqui. Agropecu. Bras. 29: 1099-1109.

Paiva, J.R. and Kageyama, P.Y. (1993). Novo enfoque do melhoramento da seringueira para a região amazônica. Pesqui. Agropecu. Bras. 28: 13911398.

Paiva, J.R., Miranda Filho, J.B., Siqueira, E.R. and Valois, A.C.C. (1982). Predição do ganho de alguns caracteres em seringueira em três esquemas de seleção. Pesqui. Agropecu. Bras. 17: 1646-1653.
Pereira, M.B. and Vencovsky, R. (1988). Limites da seleção recorrente. I. Fatores que afetam o acréscimo das frequiências alélicas. Pesqui. Agropecu. Bras. 23: 769-780.

Rawlings, J.O. (1970). Present status of research on long- and short-term recurrent selection on finite populations. Choice of population size. In: Proceedings of the 2nd Meeting of the Working Group on Quantitative Genetics. USDA-SFES, New Orleans, pp. 1-15.

Resende, M.D.V. and Bertolucci, F.L.G. (1995). Maximization of genetic gain with restriction on effective population size and inbreeding in Eucalyptus grandis. In: Proceedings of the CRCTHF-INFRO Conference, Hobart, pp. 167-170.

Resende, M.D.V. and Higa, A.R. (1994). Maximização da eficiência da seleção em testes de progênies de Eucalyptus através da utilização de todos os efeitos do modelo matemático. Bol. Pesqui. Florestal 28/29: $37-56$.

Resende, M.D.V., Oliveira, E.B., Melinski, L.C., Goulart Junior, F.S. and Oaida, G.R.P. (1994). Seleção Genética Computadorizada - Selegen "Best Prediction". Manual do Usuário. Embrapa Floresta, Colombo.

Resende, M.D.V., Araujo, A.J., Sampaio, P.T.B. and Wiecheteck, A.S. (1995). Acurácia seletiva, intervalos de confiança e variância de ganhos genéticos associados a 22 métodos de seleção em Pinus caribaea var. hondurensis. Rev. Floresta 24: 35-45.

Robertson, A. (1960). A theory of limits in artificial selection. In: Proceedings of the Royal Society Conference. Royal Society, London, pp. 234-249.

Tan, H. and Subramanian, S. (1975). A five-parent diallel cross analysis for certain characters of young Hevea seedlings. In: Proceedings of the International Rubber Conference RRIM, Kuala Lumpur, pp. 13-16.

Tan, H., Mukherjee, T.K. and Subramanian, S. (1975). Estimates of genetic parameters of certain characters in Hevea brasiliensis. Theor. Appl. Genet. 46: 181-190.

Van Vleck, L.D., Pollack, E.J. and Oltenacu, E.A. (1987). Genetics for the Animal Sciences. W.H. Freeman and Co., New York.

Vencovsky, R. (1978). Effective size of monoecious populations submitted to artificial selection. Rev. Bras. Genet. I: 181-191.

Vencovsky, R. (1987). Herança quantitativa. In: Melhoramento e Produção do Milho (Paterniani, E. and Viegas, G.P., eds.). Fundação Cargill, Campinas, pp. 137-214.

Vencovsky, R. and Godoy, C.R.M. (1976). Immediate response and probability of fixation of favorable alleles in some selection schemes. Proceedings of the 9th International Biometric Conference, Boston, 1976, pp. 180-185.

(Received July 6, 1999) 